\title{
DIAGNOSTIC VALUE OF URIC ACID IN PLEURAL EFFUSION
}

\author{
Saraswati Wulandari Hartono ${ }^{1}$, Nurhayana Sennang ${ }^{1}$, Fitriani Mangarengi ${ }^{2}$ \\ ${ }^{1}$ Department of Clinical Pathology, Faculty of Medicine, Hasanuddin University/Wahidin Sudihusodo Hospital, Makassar, \\ Indonesia. E-mail: sarashartono1201@gmail.com ²Department of Clinical Pathology, Faculty of Medicine, Hasanuddin \\ University/Syekh Yusuf Hospital, Gowa, Indonesia
}

\section{ABSTRACT}

Pleural effusion is excessive pleural fluid accumulation in the aimed pleural cavity, are categorized into exudate and transudate. Light's criteria (1972) has become a classic criteria to distinguish pleural effusion types. Other criteria were evaluated such as pleural fluid uric acid. The aimed of this study was to analyze the difference of uric acid level between transudate and exudate and to compare it with Light's criteria. A crosssectional study was conducted in Clinical Pathology Laboratory of the Dr. Wahidin Sudirohusodo Hospital Makassar in September 2016. Uric acid level of pleural effusion samples was measured by ABX Pentra 400. Statistical analysis used Mann-Whitney $U$ test, significance was indicated if $p<0.05$. Cut-off, sensitivity and specificity of uric acid used ROC curve. Total subjects were 56 patients, mean age $49.54 \pm 13.63$ years-old, 31 males (55.4\%) and 25 females (44.6\%). Most cases were exudative effusion (58.9\%) with 19 malignancy cases (33.9\%). Uric acid level median was $6.6 \mathrm{mg} / \mathrm{dL}(3.24-17.50 \mathrm{mg} / \mathrm{dL})$ higher in transudate than exudate $5.01 \mathrm{mg} /$ $\mathrm{dL}(0.6-9.40 \mathrm{mg} / \mathrm{dL})(\mathrm{p}=0.001)$. The cut-off point for pleural fluid uric acid was $5.845 \mathrm{mg} / \mathrm{dL}$, with a sensitivity of $78.3 \%$ and specificity of $66.7 \%$. Sensitivity and specificity of Light's criteria was $97 \%$ and $60.9 \%$. There was a significant difference between pleural fluid uric acid level in transudate and exudate, higher in transudate than exudate. Light's criteria were higher in sensitivity than uric acid, but lower in specificity. Further research is needed with better sampling method to reduce bias.

Key words: Uric acid, pleural effusion, Light's criteria

\section{INTRODUCTION}

Pleural cavity located between the visceral and parietal pleura is, normally filled with thin fluid approximately 1-10 $\mathrm{mL}$. The pleural fluid serves as a lubricant between the two pleural surfaces in respiration. The balance of fluid in the pleural cavity is maintained by colloid osmotic pressure, capillary permeability and hydrostatic pressure. Pleural fluid in normal circumstances is formed slowly as plasma filtration through capillaries and then reabsorbed via the lymph vessels around the pleura. ${ }^{1,2}$

Pleural effusion is excessive pleural fluid accumulation in the pleural cavity, caused by excessive production or an absorption disorder, or both of them. Pleural effusion is a common manifestation of pleural abnormalities that caused by a variety of diseases, ranging from cardiovascular disease, inflammatory or malignant diseases that require further evaluation and therapy. ${ }^{3}$ Pleural effusion can be categorized into exudate or transudate based on the pathogenesis. Transudate occurs due to changes in hydrostatic pressure or oncotic systemic, without pathological abnormalities in the structure of the pleura or the walls of blood vessels. Exudate is caused by a local pathology disorder or structural damage to the pleura. ${ }^{4,5}$

Uric acid is a product of catabolism of nitrogencontaining products especially purines, either from diet or endogenous nucleic acids which are Deoxyribonucleic Acid (DNA) and Ribonucleic Acid (RNA). Uric acid in the circulation derived from the degradation of a normal dietary source and dead body cells. ${ }^{6}$ Uric acid with low molecular weight $(168 \mathrm{~g} / \mathrm{mol})$ based on studies can be found in the pleural fluid. ${ }^{2,7,8}$ Increasing uric acid levels can be found in clinical conditions that cause oxidative stress and tissue hypoxia, such as obstructive lung disease, congestive heart failure and others. Depletion of cellular oxygen results in Adenosine Triphospate (ATP) degradation into hypoxanthine, xanthine and uric acid. ${ }^{2,7}$ 
Light's criteria introduced in 1972, has become a classic criteria to distinguish exudate from transudate. Fluid is considered exudative if it meets one or more of the following criteria: pleural/serum protein ratio of > 0.5 ; the pleural/serum $\mathrm{LDH}$ ratio of $>0.6$; and/or the pleural fluid Lactate Dehydrogenase (LDH) greater than $200 \mathrm{U} / \mathrm{II})^{7,9}$ In a recent article, Porcel reported that Light's criteria had a very high sensitivity (98\%) but lower specificity (73\%). ${ }^{10}$

Several recent articles have evaluated alternative criteria for the distinction of transudate and exudate, such as a pleural fluid uric acid level. Hazarika et al. Found that pleural fluid uric acid levels were higher in transudate than exudate with a cut-off $5.35 \mathrm{mg} / \mathrm{dL}$, sensitivity of $89.32 \%$ and specificity of $92.60 \% .^{5}$ Jain et al. Also found pleural fluid uric acid level higher in transudate than exudate with a cut-off $5.5 \mathrm{mg} / \mathrm{dL}$, sensitivity of $94 \%$ and specificity of $83 \%{ }^{2}$

Considering these alternative criteria, resecrhers are interested in comparing the two criteria mentioned above in determining the type of pleural fluid, to find a more accurate, applicable and inexpensive test. Thus, the result of this study can be used as a reference to the clinicians in selecting an effective and efficient test.

The aimed of this study was to evaluate the difference of pleural fluid uric acid level between transudate and exudate and to compare it with Light's criteria.

\section{METHODS}

A cross-sectional study of 56 pleural fluid specimens was conducted in Clinical Pathology Laboratory of the Dr. Wahidin Sudirohusodo Hospital Makassar in September 2016. Pleural fluid specimens were obtained from thoracocentesis procedure by Pulmonologist on the ward and then the analysis was performed in the Clinical Pathology Laboratory. Patients having pleural effusion secondary to trauma, were excluded from this study. Uric acid pleural fluid levels were analyzed using a chemical autoanalyzer (ABX Pentra 400), colorimetric method.

Samples were therefore divided into two groups as transudative effusion or exudative effusion based on standard methods of diagnosis and Light's criteria. Malignancies were confirmed by cytology examination. Infections were confirmed by positive microbial culture and acid-fast bacilli smear. Congestive heart failure, chronic kidney disease and liver cirrhosis were confirmed by clinical examination, radiological examination and others. Exudates were sepa- rated from transudates by Light's criteria if one of the following three criteria was met: pleural/serum protein ratio of $>0.5$; the pleural/serum LDH ratio of $>0.6$; and/or the pleural fluid lactate dehydrogenase (LDH) greater than $200 \mathrm{U} / \mathrm{I})$.

From normality test using Shapiro-Wilk Test, data were found not normally distributed, then data was reported in median (minimum-maximum). Statistical analysis was done with Mann-Whitney $U$ test, $p$-value less than 0.05 was considered statistically significant with confidence interval $95 \%$. Receiver Operating Characteristic (ROC) curves were calculated for evaluating the optimum cut-off points, sensitivity and specificity of uric acid levels. Sensitivity and specificity of Light's criteria were calculated by $2 \times 2$ table.

\section{RESULTS AND DISCUSSION}

Fifty-six specimens of pleural fluid from 56 patients were obtained, 31 patients were males $(55.4 \%)$ and 25 were females (44.6\%), with a mean age of $49.54 \pm 13.63$ years (range 14-76 years). Most specimens was from the age group of 40-59 years, consisting of 31 patients (55.4\%) as seen in Table 1. This result was relevant with Surjanto et al., ${ }^{11}$ study at the Dr. Moewardi Hospital (RSDM) Surakarta during the period January 1 until December 31 2012, that the number of patients with pleural effusion was more in males, with the largest age group between $41-60$ years. ${ }^{11}$

Patients with transudative pleural effusion were 23 (41.1\%), 10 of them were males (43.5\%) and 13 females (56.5\%), with a mean age of $53.43 \pm$ 13.66 years (26-76 years). Exudative pleural effusion with a total of $33(58.9 \%), 21$ of them were males (63.6\%) and 12 females (36.4\%), with a mean age of $46.82 \pm 13.13$ years (14 -71 years) (Table 2 ).

Most cases was exudative pleural effusion (58.9\%). This was in line with Hazarika et al., ${ }^{5}$ who found exudate as the largest case (79.24\%). ${ }^{5}$ Based on this study, most of the transudative pleural effusion was caused by chronic renal failure in 13 cases (23.2\%). Most of the exudative pleural effusion caused by malignancy in 19 cases (33.9\%). This was in line with Surjanto et al. Study that malignancy was the most cause of pleural effusion. ${ }^{11}$ Etiology of pleural effusion is shown in Table 3.

Increases in uric acid level in transudate may be found in clinical conditions associated with tissue hypoxia and oxidative stress. ${ }^{7}$ Oxidative stress hap- 
Table 1. Sex and age distribution characteristic of pleural effusion patients

\begin{tabular}{|c|c|}
\hline Variables & n (\%) \\
\hline \multicolumn{2}{|l|}{ Sex } \\
\hline Male & $31(55.4)$ \\
\hline Female & $25(44.6)$ \\
\hline \multicolumn{2}{|l|}{ Age distribution } \\
\hline$<20$ years & $1(1.8)$ \\
\hline $20-39$ years & $11(19.6)$ \\
\hline $40-59$ years & $31(55.4)$ \\
\hline$\geq 60$ years & $13(23.2)$ \\
\hline
\end{tabular}

Table 2. Age distribution and sex of patients based on the type of effusion by diagnosis

\begin{tabular}{lcc}
\hline \multicolumn{1}{c}{ Variables } & $\begin{array}{c}\text { Transudate } \\
(\mathbf{n = 2 3 )}\end{array}$ & Exudate $(\mathbf{n = 3 3 )}$ \\
\hline Age mean (years) & $53.43 \pm 13.66$ & $46.82 \pm 13.13$ \\
Sex $\quad$ Male & $10(43.5 \%)$ & $21(63.6 \%)$ \\
$\quad$ Female & $13(56.5 \%)$ & $12(36.4 \%)$ \\
\hline
\end{tabular}

Table 3. Sample distribution based on diagnosis and mean of uric acid levels

\begin{tabular}{lcc}
\hline Diagnosis & $\mathrm{n}(\%)$ & $\begin{array}{c}\text { Mean of uric } \\
\text { acid levels } \\
(\mathrm{mg} / \mathrm{dL})\end{array}$ \\
\hline $\begin{array}{l}\text { Transudates } \mathrm{n}=23(41.1 \%) \\
\quad \text { Congestive heart failure }\end{array}$ & $8(14.3)$ & $8.32 \pm 3.01$ \\
$\quad$ Chronic kidney disease & $13(23.2)$ & $6.68 \pm 2.25$ \\
$\quad$ Liver cirrhosis & $2(3.6)$ & $10.95 \pm 9.26$ \\
Exudates $\mathrm{n}=33(58.9 \%)$ & $19(33.9)$ & $4.62 \pm 2.19$ \\
$\quad$ Malignancy & $14(25)$ & $5.63 \pm 1.15$ \\
\hline Infection & &
\end{tabular}

pened in patients with chronic renal failure. Patients with chronic renal failure receiving hemodialysis experienced hypoxemia during routine dialysis. ${ }^{12}$ The same applied to patients with congestive heart failure who turn hypoxemic. Similarly, liver cirrhosis is often associated with oxidative stress. A variety of cytokines like TNF- $\alpha$ can be produced in Kupffer cells induced by oxidative stress, which might increase inflammation and apoptosis. With regard to hepatic stellate cells, the proliferation and collagen synthesis of hepatic stellate cells are triggered by oxidative stress. ${ }^{5,13}$ Depletion of cellular oxygen results in Adenosine Triphosphate (ATP) degradation into hypoxanthine, xanthine and uric acid. ${ }^{2,7}$
Table 4. Pleural fluid uric acid levels

\begin{tabular}{lccc}
\hline \multirow{2}{*}{ Variable } & Transudate & Exudate & \\
\cline { 2 - 3 } & $\begin{array}{c}\text { Median (min } \\
- \text { max) }\end{array}$ & $\begin{array}{c}\text { Median } \\
(\text { min-max) }\end{array}$ & p-value \\
\hline Uric Acid & 6.6 & $\begin{array}{c}5.01 \\
(0.6-9.40)\end{array}$ & $0.001^{*}$ \\
\hline Normality test, Shapiro-Wilk test: $\mathrm{p}<0.05 ;$ data distribution not \\
normal \\
*Mann-Whitney U test: $\mathrm{p}<0.05 ;$ significant
\end{tabular}

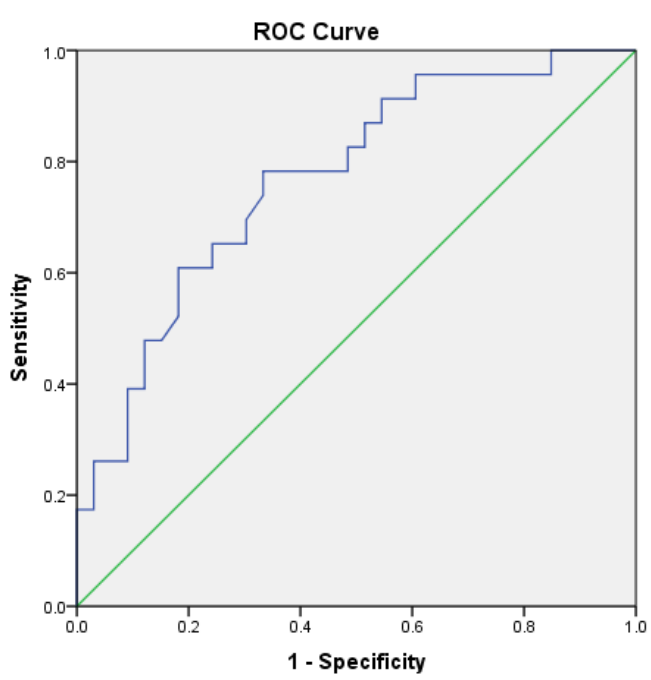

Figure 1. ROC curve of pleural fluid uric acid levels

A Receiver Operating Characteristic (ROC) curve of pleural uric acid (Figure 1), has been done to determine the demarcating cut-off value between exudates as compared to transudates. The optimum cut-off level for pleural uric acid was more than $5.845 \mathrm{mg} / \mathrm{dL}$ in transudate, with a sensitivity and specificity of pleural uric acid in differentiating between transudate and exudate pleural effusion of $78.3 \%$ and $66.7 \%$, respectively. These results were different from Jain et al., ${ }^{2}$ study who stated that the cut-off level was $5.5 \mathrm{mg} / \mathrm{dL}$ with higher sensitivity and specificity of $94 \%$ and $83 \%$, also Hazarika et al. Study wich stated that the cut-off level was $5.35 \mathrm{mg} / \mathrm{dL}$, sensitivity $89.32 \%$ and specificity $92.60 \% .^{2,5}$

In this study there were 5 cases based on diagnosis categorized as transudate ( 3 cases chronic kidney disease, 1 case liver cirrhosis and 1 case congestive heart failure) but, had the uric acid level below 5.845 $\mathrm{mg} / \mathrm{dL}$ (exudate). There were 11 cases based on diagnosis categorized as exudate (4 cases lung tumor, 1 case endometrium carcinoma metastases to lung, 1 case sepsis, 2 cases lung tuberculosis and 3 cases 
pneumonia) but, had the uric acid level higher than $5.845 \mathrm{mg} / \mathrm{dL}$ (transudate). It was assumed that was due to the limitation of this study because of uses of previous treatment which can influence uric acid level, such as uricosuric drugs, diuretic and chemotherapy were not controlled. Uricosuric drugs used in chronic kidney disease can decrease uric acid level. Diuretic therapy in pleura effusion patient can increase uric acid levels. Chemotherapy can increase uric acid level since degradation of dead tumor cells will be converted into uric acid. ${ }^{7,9}$ transudate than exudate. The sensitivity of Light's criteria $(97 \%)$ was higher than uric acid pleural fluid level (78.3\%), but, its specificity (60.9\%) was lower than uric acid pleural fluid level (66.7\%). However, the limitation of this study that there was no control in uses of previous treatment which could influence uric acid level. Further studies are needed with better sampling method to reduce bias.

\section{ACKNOWLEDGEMENT}

I would like to express my deep gratitude to $d r$.

Table 5. Exudate and transudate categorized based on diagnosis and uric acid level (cut-off $5.845 \mathrm{mg} / \mathrm{dL}$ )

\begin{tabular}{llcccc}
\hline & & \multicolumn{2}{c}{ Diagnosis } & \multicolumn{2}{c}{ Total } \\
\cline { 3 - 6 } & & Transudate & Exudate \\
\hline Uric acid & & 18 & 11 & 29 \\
\cline { 3 - 6 } cut-off $5.845 \mathrm{mg} / \mathrm{dL}$ & Transudate & Exudate & 23 & 22 & 27 \\
\hline & Total & & 53 & 56 \\
\hline
\end{tabular}

Table 6. Exudate and transudate categorized based on diagnosis and Light's criteria

\begin{tabular}{llcccc}
\hline & & \multicolumn{3}{c}{ Total } \\
\cline { 3 - 6 } & & & Diagnosis & \multicolumn{2}{c}{ Transudate } \\
\cline { 3 - 6 } $\begin{array}{l}\text { Light's } \\
\text { criteria }\end{array}$ & & Exudate & 32 & 9 & 41 \\
\hline & Total & & 1 & 14 & 15 \\
\hline
\end{tabular}

Sensitivity and specificity of Light's criteria in differentiating between transudate and exudate pleural effusion using $2 \times 2$ table were $97 \%$ and $60.9 \%$, respectively (Table 6). One case based on diagnosis categorized as exudate (mediastinum tumor metastases to lung) was by Light's criteria categorized as transudate. Nine cases based on diagnosis categorized as transudate (6 cases chronic kidney disease, 3 cases congestive heart failure) were (Light's criteria) categorized as exudate.
Fitriani Mangerangi, Sp.PK(K) and Dr. dr. Nurhayana Sennang, M.Kes, Sp.PK, DMM, my research supervisors, for their patient guidance, enthusiastic encouragement and useful critiques of this research work. I would also like to extend my thanks to the technicians of the laboratory of Clinical Pathology Wahidin Sudirohusodo Hospital for their help in running the samples.

Finally, I wish to thank my parents and husband for their support and encouragement throughout my study.

Table 7. Sensitivity and specificity of each criteria comparing with the diagnosis

\begin{tabular}{lcc}
\multicolumn{1}{c}{ Criteria } & $\begin{array}{c}\text { Sensitivity } \\
\text { (\%) }\end{array}$ & Specificity (\%) \\
\hline Pleural fluid uric acid (cut-off $5.845 \mathrm{mg} / \mathrm{dL}$ ) & 78.3 & 66.7 \\
Pleural fluid uric acid (cut-off $4.63 \mathrm{mg} / \mathrm{dL}$ ) & 91.3 & 45.5 \\
Pleural fluid uric acid (cut-off $7.525 \mathrm{mg} / \mathrm{dL}$ ) & 39.1 & 90.9 \\
Light's criteria & 97 & 60.9 \\
\hline
\end{tabular}

\section{CONCLUSION AND SUGGESTION}

This study indicated that there was a significant difference between pleural fluid uric acid level in transudate and exudate, which was higher in

\section{REFERENCES}

1. Nurahmi, Wibawa SY, Badji A, Hardjoeno. Tes dan Interpretasi Pleural fluid. Dalam: Hardjoeno, Fitriani, editors. Substansi dan Cairan Tubuh. Makassar, Lembaga Penerbi- 
tan Universitas Hasanuddin, 2011; 67-84.

2. Jain A, Jain R, Petkar SB, Gupta SK, Khare N, Dutta J. A Study of Uric Acid - A New Biochemical Marker for The Differentiation between Exudates and Transudates in Pleural Effusion Cases. NJCM. 2014; 5(2): 204-8.

3. Rubins J. Pleural Effusion. 2014 [accesed September 4, 2014]; Available from: http:// emedicine.medscape.com/article/299959overview\#showall.

4. Sato T. Differential Diagnosis of Pleural Effusions. JMAJ. 2006; 49(9-10): 315-9.

5. Hazarika B, Raghavendra MK, Sarma J, Sarmah KR. Role of Pleural Fluid Uric Acid Estimation In Differentiation Between Transudative and Exudative Pleural Effusion. The Pulmo-Face. 2015; 15(2): 55-60.

6. Wilson DD. Uric Acid, Blood. Manual of Laboratory and Diagnostic Tests. Illinois, McGraw-Hill, 2006; 579 $-80$.

7. Uzun K, Vural H, Ozer F, Imecik O. Diagnostic Value of Uric Acid to Differentiate Transudates and Exudates. Clin Chem Lab Med. 2000; 38(7): 661-5.
8. National Center for Biotechnology Information. PubChem Compound Database CID1175; [accessed June 15, 2016]; Available from: https://pubchem.ncbi.nlm.nih.gov/ compound/1175.

9. Light RW. Disorders of The Pleura and Mediastinum. In: Loscalzo J, editor. Harrisons's Pulmonary and Critical Care Medicine. $17^{\text {th }}$ Ed., San Fransisco, McGraw Hill Medical, 2010; 215-9.

10. Porcel JM. Identifying misclassified by Light's criteria. Curr Opin Pulm Med. 2013; 19(4): 362-367.

11. Surjanto E, Sutanto YS, Aphridasari J, Leonardo. Penyebab Efusi Pleura pada Pasien Rawat Inap di Rumah Sakit. J Respir Indo. 2014; 34(2): 102-8.

12. Alfakir M, Moammar MQ, Ali MI, Alhatem E, Curran RD, Saoud RM, et al. Pulmonary Gas Exchange During Hemodialysis: A Comparison of Subjects with and without COPD on Bicarbonate Hemodialysis. Ann Clin Lab Sci. 2011; 41 (4): 315-20.

13. Li S, Tan HY, Wang N, Zhang ZJ, Lao L, Wong CW, et al. The Role of Oxidative Stress and Antioxidants in Liver Diseases. Int J Mol Sci. 2015; 16(11): 26087-90. 